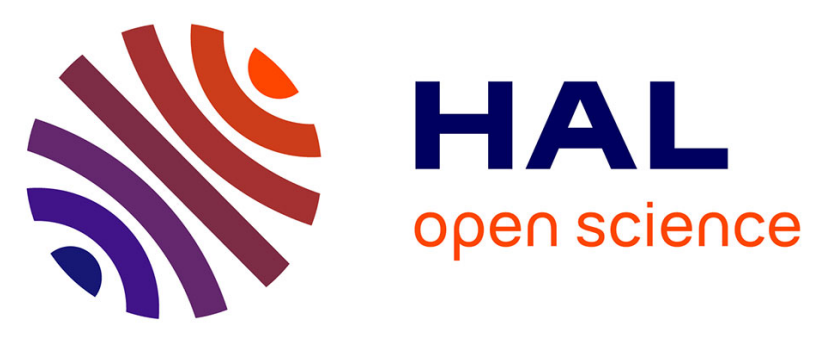

\title{
Backward waters, modern waters: Perception-Based Regional Mapping territory uses and water-related sanitary stakes in Luang Phabang area (Lao PDR)
}

Mehdi Saqalli, Marine Jourdren, Nicolas Maestripieri, Sylvie Guillerme, Eric Maire, Bounsamai Soulileuth, Keoudone Latsachach, Phabvilay Sounyafong, Louy Tammahuxsa, Oloth Sengtaheuanghoung, et al.

\section{To cite this version:}

Mehdi Saqalli, Marine Jourdren, Nicolas Maestripieri, Sylvie Guillerme, Eric Maire, et al.. Backward waters, modern waters: Perception-Based Regional Mapping territory uses and water-related sanitary stakes in Luang Phabang area (Lao PDR). Applied Geography, 2015, 60, pp.184-193. 10.1016/j.apgeog.2015.04.001 . hal-01187590

\author{
HAL Id: hal-01187590 \\ https://hal.science/hal-01187590
}

Submitted on 27 Aug 2015

HAL is a multi-disciplinary open access archive for the deposit and dissemination of scientific research documents, whether they are published or not. The documents may come from teaching and research institutions in France or abroad, or from public or private research centers.
L'archive ouverte pluridisciplinaire HAL, est destinée au dépôt et à la diffusion de documents scientifiques de niveau recherche, publiés ou non, émanant des établissements d'enseignement et de recherche français ou étrangers, des laboratoires publics ou privés. 


\title{
Backward waters, modern waters: Perception-Based Regional Mapping territory uses and water-related sanitary stakes in Luang Phabang area (Lao PDR)
}

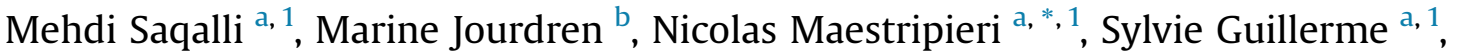 \\ Eric Maire a, 1, Bounsamai Soulileuth ${ }^{c}$, Keoudone Latsachach ${ }^{c}$, Phabvilay Sounyafong ${ }^{\text {, }}$, \\ Louy Tammahuxsa ${ }^{c}$, Oloth Sengtaheuanghoung ${ }^{d}$, Olivier Ribolzi ${ }^{\mathrm{e}}$, Sylvia Becerra ${ }^{\mathrm{e}}$ \\ a Department of Geography, University Toulouse II, GEODE UMR 5602 CNRS, France \\ ${ }^{\mathrm{b}}$ Institut d'Etudes Politiques (IEP), Toulouse, France \\ ${ }^{c}$ Institut de Recherche pour le Développement (IRD), Vientiane, Lao People's Democratic Republic \\ ${ }^{\mathrm{d}}$ National Agriculture and Forestry Research Institute (NAFRI), Vientiane, Lao People's Democratic Republic \\ e Géosciences Environnement Toulouse (GET), UMR 5563 CNRS, France
}

\section{A R T I C L E I N F O}

Article history:

Available online 29 April 2015

\section{Keywords:}

Laos

Perception-Based Regional Mapping

Health risk exposure

Sanitation cover

LUCC

\begin{abstract}
A B S T R A C T
This paper examines the suitability of the PBRM, a mapping tool based on the perceptions of local stakeholders, for assessing the connection between land uses and health issues. The area, rural Laos around Luang Phabang city, between the Mekong River valley and mountains, seems to have overcome the formal territorial organization based on exposure risks towards an organization based on access to health and medical facilities. In addition, differential access to safe drinking water has been quite solved by the implementation of private can distribution networks. However, these rapid changes accentuate the social gap between well-connected lowlands and valleys on one hand, and mountain areas on the other hand, increasingly sidelined from this transition. Methodologically, PBRM method explores broader issues at a broader scale but does not give an easy access to non-spatial criteria. Plus, the limits of the SHUs (Spatial Homogeneous Unit) the PBRM establishes are geographically precise regarding topology but not spatiality. These results are action-oriented towards local and development-oriented issues.
\end{abstract}

(c) 2015 Elsevier Ltd. All rights reserved.

\section{Introduction}

Water-related diseases are now the leading cause of death for humanity, overcoming AIDS and other diseases, all geographical and social backgrounds together (WHO-UNICEF, 2006). The issue is

\footnotetext{
* Corresponding author. Tel.: +33 (0)5 61503626 .

E-mail addresses: mehdi.saqalli@univ-tlse2.fr (M. Saqalli), jourdren.marine@ gmail.com (M. Jourdren), nicolas.maestripieri@univ-tlse2.fr (N. Maestripieri), sylvie.guillerme@univ-tlse2.fr (S. Guillerme), eric.maire@univ-tlse2.fr (E. Maire), sbounsamay@gmail.com (B. Soulileuth), wannaki@gmail.com (K. Latsachach), phabvilay_laopdr@yahoo.com (P. Sounyafong), louy_tam@yahoo.com (L. Tammahuxsa), oloth_s@hotmail.com (O. Sengtaheuanghoung), olivier.ribolzi@ get.obs-mip.fr (O. Ribolzi), sylvia.becerra@get.obs-mip.fr (S. Becerra).

URL: http://w3.geode.univ-tlse2.fr/permanents/saqalli.php

1 CNRS UMR 5602 GEODE Géographie de l'Environnement, Maison de la Recherche, Université Toulouse le Mirail, 5, Allées Antonio Machado 31058, Toulouse, France. Tel.: +33 (0)6 160380 37, +33 (0)5 61502440 .
}

even more accurate in rural and periurban areas where access to water sanitation and medical infrastructures may remain limited.

Moreover, water sanitation and medical infrastructures are susceptible to flooding due to monsoon rains. Thus, beyond the physical risk and damage done to infrastructure, flooding periods are very conducive to the spread of water related disease agents through wells, boreholes or reservoirs. In Southeast Asia, situations are very changeable and contrasting. If great plains and deltas of the peninsula like lowlands of the Mekong are indeed subject to strong floods, these ones are regular, channelled and (quite) managed. Their health impacts are even more controlled as these plains are home to the economic and political development. Mountain areas in Laos are not spared from floods, which are there brutal, irregular and less predictable. Long distance and poor road networks are obstacles to a good access to both water and health infrastructures.

Our hypothesis is that the risk of exposure to microbiological contaminants depends not only on sanitary conditions or the proximity of dwellings to water sources (canals, streams, wells, 
boreholes or tanks) but also to socio-institutional factors from which policy incentives, accessibility to remediation infrastructures and social practices play a major role.

Lao P.D.R. is a mostly a rural country ( $78 \%$ of the population) with poor living standards (Human Development Index ranking $133^{\text {rd }}$ out of 179 countries: Ribolzi et al., 2011). Meanwhile, the country experienced, along an overall economic upgrade in Southeast Asia, a major economic shift towards higher livelihood levels with $8.3 \%$ of economic growth for 2012. Such a growth is indeed an opportunity for an improvement of the national scheme regarding sanitation and health remediation facilities but also of public policies related to health and water issues (UN-Habitat, 2008). It means also adapting such a scheme to the already and on-going transformation of the issues themselves (Lestrelin \& Giordano, 2006; Mekong River Commission, 2010).

Following Campbell (2007) and Ribolzi et al. (2011), such an evaluation program encounters many difficulties: data are lacking on both contamination sources and water-related diseases due to the scarcity of field investigations and measurements, but also on the social practices and the real impact of public policies "on-theground".

A diagnosis of the exposure to water-related diseases and preventing infrastructures is constrained by the dedicated time and funds but also to the scientific disciplines they belong (Komany, 2008). For instance, contamination does not imply sicknesses: people may be not confronted to contaminated water by contact, may not drink this water and if not, may still asymptomatic. Furthermore, being geographically proximate to water doesn't necessarily mean that a person has been exposed to pathogens that are related to water. Water borne diseases are so heterogeneous that it is difficult to consider them as a single entity. On the other hand, consequences of water-related exposures are reduced by effective and efficient sanitation, hygiene and health infrastructures but this evaluation should include an overall description of both their effectivities and accessibilities. Following Olivier de Sardan (2010), one should acknowledge that such an evaluation is sensitive: health issues are politically interesting for everyone, meaning results, assumptions and policy choices are not neutral. Moreover, such issues are related to many scientific disciplines (epidemiology, hydrology, agronomy/agriculture, economy, political sciences, geography, etc.) that did not elaborate a structured dialogue yet. One should then look for a tool that can support the assessment of this evaluation. For instance, the Participatory Rural Appraisals (PRAs) (Chambers, 1994; Loader \& Amartiya, 1999; Olivier de Sardan, 2003) are a combination of community-based tools including mental spatial representation. Various participatory mapping methods include this spatial knowledge and combine it with Geographic Information Systems (Nackoney, Rybock, Dupain, \& Facheux, 2013; Norris, 2014). However these representation are not geographically positioned and practically, they are of no use after their establishment: they cannot be confronted to other sources nor they can be combined altogether or with other data. Therefore, this paper presents the methodology and the results of such an evaluation, using the Perception-Based Regional Mapping (PBRM).

\section{Methodology}

\section{Global overview}

The PBRM is a tool that have been used in several locations: Brazil 1996 (Caron, 2001), South Africa 1998, Vietnam 1999 (Saqalli \& Dosso, 2011), France 2003, Niger 2005-2006 (Saqalli, Caron, Defourny, \& Issaka, 2009), Tunisia 2008; Madagascar, 2011; Tunisia 2013 (Saqalli et al. 2013), Ecuador 2013-2014 (Maestripieri et al. 2014) and adapted to this health issue we are concerned with. The study has been assessed in the northern part of Lao P.D.R., around the city of Luang Phabang through two field surveys, in June and October 2012 (Fig. 1). The first survey focused on the local perceptions regarding the territory and the second survey focused on health issues.

The overall methodology consists on a confrontation between socio-environmental mapped informations, respectively territory (called thereby PBRM territory) and health (called thereby PBRM health). Two maps were then assessed, each one corresponding to a field mission. The studied territory covers around $35^{*} 50 \mathrm{~km}$, meaning a territory of $1840 \mathrm{Km}^{2}$. The choice of this site is due:

- To the potential risk of water-related diseases in tropical and developing areas with high slopes and mountains;

- Based on the above factor, the high involvement of the Laotian government regarding water-related diseases but also land use issues, according to the assumption that land use, slopes, soil erosion, turbidity and water-related diseases are connected;

- Based on the two previous factors, the involvement of the scientific communities, concerning various disciplines from which hydrogeology plays a major role, from Laos PDR and abroad, thanks to the settlement and the implementation of several international research projects and collaborations (M-SEC: Management of Soil Erosion Consortium: alternative farming practices to combat land degradation and improve household livelihoods; , PASTEK: impacts of global change on water resources in terms of volume and quality in the Nam Khan basin; MIASMES: Flood-Related Diseases: A Socio-spatial Approach of Mekong and its tributaries);

Both zonings are based on the methodology that was formalized in Saqalli et al. (2009), issued itself from the work of Caron (2001). We have adapted this tool to the specific geographical, socioanthropological and political context of Laos PDR but also to the specific health issues we raise in this research. The work means interviewing two people using a map, a geographical medium readable by all, and a tracing paper, i.e. a layer which holds the information to be collected. This exercise should be repeated to improve the reliability of the result. For both maps, we used as a support the same GIS-reconstructed map after the 1:200,000 map assessed around 1985 by the Laotian Geographic Institute with the support of Soviet geographic services. The map we built includes Luang Phabang District and portions of Chômphet and XiengnGeun Districts, all of them parts of Luang Phabang Province (Fig. 1).

\section{Organizing the interviews}

For each mapping session, the area must be divided in as many pieces as there are field days available: we therefore selected "urban" centres or well-dispersed quite big villages, so as to fully cover the area, but also to interview as many diverse people as possible, as diverse regarding social positions and with as many knowledge as possible. Generally, two persons are interviewed in the same session. Each session needs quite half a day, meaning that, based on the fact that two interview sessions were assessed at the same time. Each interview session is assessed by a team of at least two interviewers, one interviewing and translating in English while the second one dedicated to write down informations on notebooks. Each workday in one village produces four PBRM maps. The selected interview places were then for both mapping sessions (Table 1):

Along Lao administrative practices, appointments with interviewees were settled alongside with District District-level Agriculture \& Forestry Officers (DAFOs). One may then 


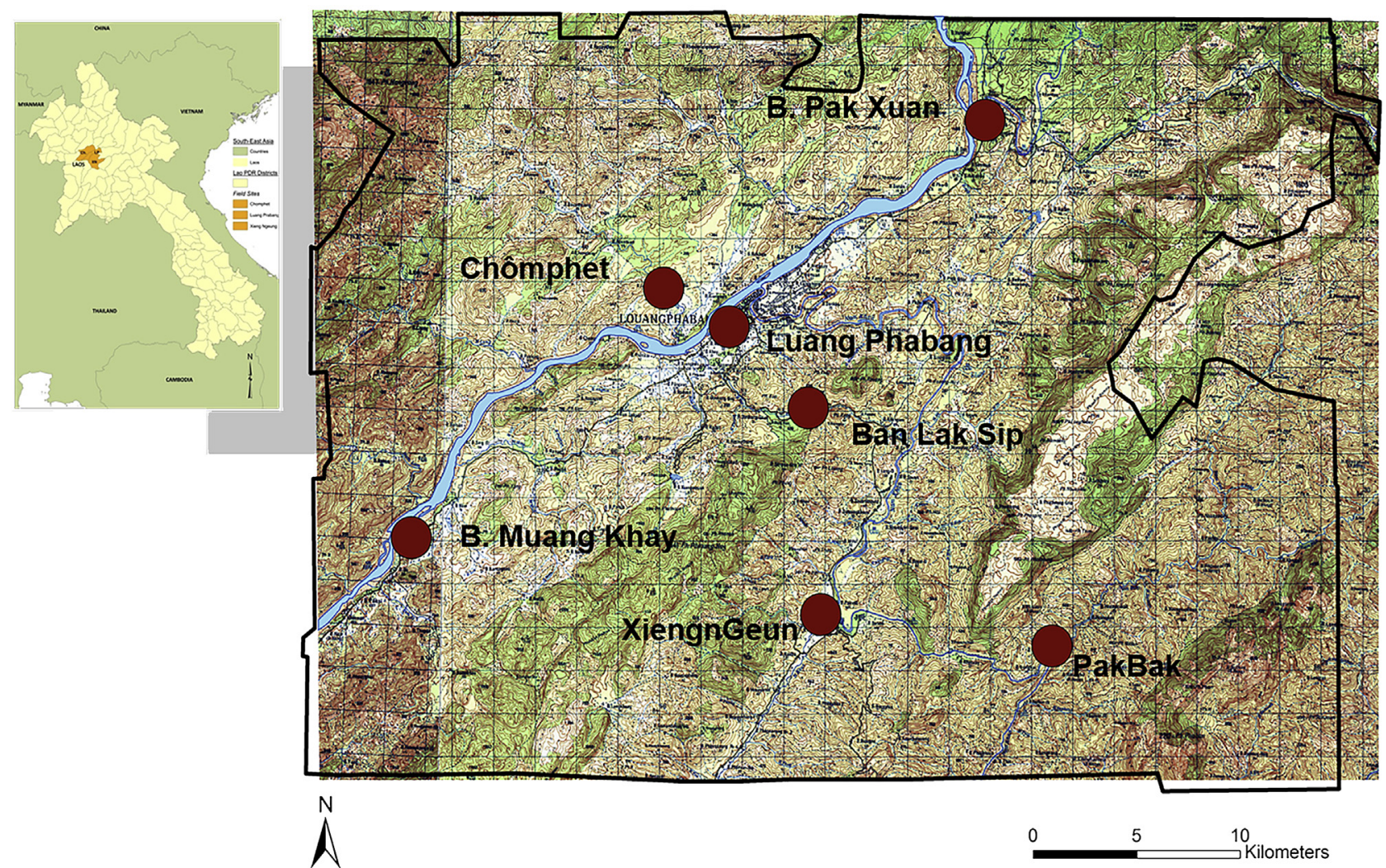

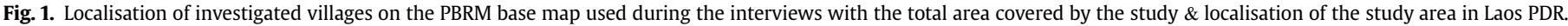

understand that such a procedure has induced two strong methodological biases:

- The first and easily observed bias is the over-representativeness of interviewed officials amongst interviewees. This bias should be nuanced by the fact that quite all villagers from small to medium villages are members of the public office groups (Each Lao PDR village adult population is structured along five groups: elders, youngsters, women, police and education, Evrard, 2006), as it is organized by the Lao policy in all villages.

- The second and more hidden bias is the fact that because people were mainly chosen by DAFO and that the majority of the interviews were assessed with the presence of local officials and DAFOs, the openness of the conversation was affected, especially regarding local discrepancies over law observances and disagreements over public policies.

Table 2 shows the distribution of professions and positions of interviewees for our survey in the two sites.
One should acknowledge that the results heavily depend on the spatial size and the accuracy of the interviewees' knowledge on the openness of the conversation, as well as the interviewers' capacity to limit the influence of social stature between themselves and interviewees and between the interviewees. The methodology is summarized in Fig. 2.

After scotching the tracing paper on the map and giving pencils to the two interviewees (1), the interview began by circling the villages they recognize (2) (The related question is "What are the villages you can talk about?") trying to connect village positions with local landmarks (roads, rivers, mountains) allowing thereby the identification of the interviewees' spatial domain of knowledge (3). One should then acknowledge the fact that we tend to get access to topological exactitude but not spatial precision. Interviewees are then asked to divide the drawn territory into units. Only the interviewees defined the criteria of differentiation, without any suggestion on the part of the interviewer (The related question is "Is it everywhere the same?" Here appear mistakes: facing hesitation and embarrassment from interviewees, the

Table 1

Characteristics of the 7 villages were surveys have been assessed.

\begin{tabular}{|c|c|c|c|c|c|c|c|}
\hline & \multirow[t]{2}{*}{ Place } & \multirow[t]{2}{*}{ District } & \multicolumn{2}{|c|}{ Number of interviewees } & \multirow[t]{2}{*}{ Characteristics } & \multirow[t]{2}{*}{ Y lat } & \multirow[t]{2}{*}{ X long } \\
\hline & & & PBRM territory & PBRM health & & & \\
\hline Luang Phabang Pho Si market & District \& Province capital & Luang Phabang & 8 & 8 & Main province centre \& market & $\mathrm{E} 102^{\circ} 07^{\prime} 4^{\prime \prime}$ & $\mathrm{N} 19^{\circ} 52^{\prime} 5^{\prime \prime}$ \\
\hline Banh $^{\mathrm{a}}$ PakXuan & Village & Luang Phabang & 8 & 8 & Bordering Mekong \& tar road & $\mathrm{E} 102^{\circ} 14^{\prime} 8^{\prime \prime}$ & $\mathrm{N} 19^{\circ} 58^{\prime} 9^{\prime \prime}$ \\
\hline Banh MuangKhai & Village & Luang Phabang & 8 & 7 & Bordering Mekong \& tar road & $\mathrm{E} 101^{\circ} 59^{\prime} 6^{\prime \prime}$ & $\mathrm{N} 19^{\circ} 46^{\prime} 5^{\prime \prime}$ \\
\hline Banh LakSip & Village & Luang Phabang & 9 & 8 & Bordering Tar road & $\mathrm{E} 102^{\circ} 09^{\prime} 9^{\prime \prime}$ & $\mathrm{N} 19^{\circ} 50^{\prime} 5^{\prime \prime}$ \\
\hline Banh ThâPho (Chômphet Dt) & Dt Capital & Chômphet & 0 & 8 & Main district urban centre \& market & $\mathrm{E} 102^{\circ} 06^{\prime} 0^{\prime \prime}$ & $\mathrm{N} 19^{\circ} 53^{\prime} 4^{\prime \prime}$ \\
\hline Banh XiengnGeun & Dt Capital & XiengnGeun & 7 & 8 & Main district centre \& market & $\mathrm{E} 102^{\circ} 10^{\prime} 1^{\prime \prime}$ & $\mathrm{N} 19^{\circ} 45^{\prime} 4^{\prime \prime}$ \\
\hline Banh PakBak & Village & XiengnGeun & 0 & 8 & Remote village & $\mathrm{E} 102^{\circ} 17^{\prime} 4^{\prime \prime}$ & $\mathrm{N} 19^{\circ} 45^{\prime} 2^{\prime \prime}$ \\
\hline Total & 7 villages & 3 districts & 40 & 55 & 95 & & \\
\hline
\end{tabular}

a Banh means "village" in Laotian. Thereby, we use to not write it or to shorten it as B. according to the way people were used to call the name of the village. 
Table 2

Distribution of interviewees according to their professions and official positions.

\begin{tabular}{|c|c|c|c|c|c|c|c|c|c|c|c|c|}
\hline \multirow[t]{2}{*}{ PBRM } & \multicolumn{6}{|c|}{ Official local position (\%) } & \multirow[t]{2}{*}{ Mean age } & \multicolumn{3}{|c|}{ Main present or past activity (\%) } & \multicolumn{2}{|c|}{ Gender (\%) } \\
\hline & $\mathrm{H}$ & HG & $\mathrm{HU}$ & 0 & MP & $\mathrm{N}$ & & Public officers & Traders & Farmers \& gardeners & Men & Women \\
\hline Territory & 10 & 16.7 & 13.3 & 23.3 & 13.3 & 23.3 & 44.6 & $22.5 w-$ & 28.5 & 49.0 & 66.1 & 33.9 \\
\hline Health & 2 & 12 & 10 & 20 & 20 & 36 & 49.2 & 12.0 & 28.0 & 60.0 & 50.9 & 49.1 \\
\hline
\end{tabular}

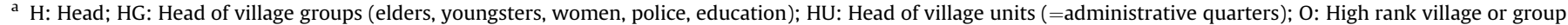
member; M: group Members; N: none.

interviewer had to stop him-/herself from "helping" people with suggestions). Interviewees should pursue the process of units' division until its evident end, when interviewees obviously see no homogeneous differences (4). In the third and last stage, the interviewers questioned the interviewees for each identified unit through a framework of factual questions (5) (What are the local infrastructure facilities (markets, dispensaries \& hospitals, schools, etc.) and production characteristics? What are the main economic activities in the unit and trade flows between it and other units? What are the dynamics of the population living in this unit, settlements \& emigration?).

\section{Synthesizing and formalizing results}

The final step for each session consisted in combining the twenty-eight maps. The task is to get a map with a limited number of well-described and relevant units. The factors chosen to determine ambiguous cases and combine the maps were the repetition of a criterion throughout interviews (In the case introducing this method, we hierarchies the criteria according to the number of repetitions multiplied by the hierarchy level of to which the criterion has been assigned. Therefore, the more a criterion has been noticed and the higher its hierarchy level, the higher it appears as discriminating for the final map) and the amount of information produced by this criterion in order to get access to as much diversity and discriminative information as possible. All the GIS operations were performed using ArcMap 10.1. Each map is geolocalized (WGS 1984/UTM zone 48 North) and all geographic features are included in an attribute table. Twenty-two criterions were identified during the interview (urban area, water access, watered fields, and so on). We performed an SQL request in order to determine which maps have the same criteria. Once the maps that described a criterion were selected, the drawings of a limit were based on a simple in-between balance between the different specific delineations, as all maps are considered with an equal importance (Fig. 2, steps (1)-(2)-(3)-(4)). Once the final map was obtained, units were discriminated in different information layers to make more explicit the different dimensions of each unit. One should notice that criteria for spatial differentiation are defined locally, meaning that legends obtained for the two sessions have not to be similar. On the other hand, the order and the way in which these criteria appear during the mapmaking process provide information on the local hierarchy of factors. Here we present selected results of the definitive maps of the two sessions, organized along the order of the first criteria to be defined by interviewees.

\section{Overlapping the map with drawing paper}

(1)
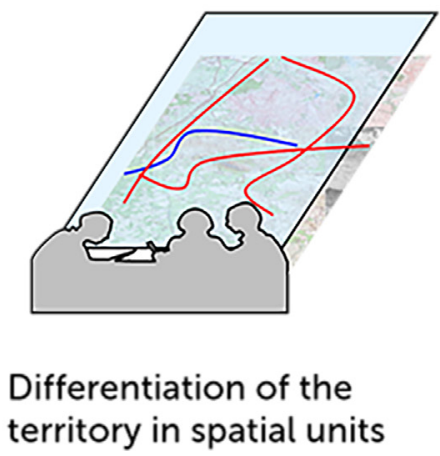

\section{Identification of villages known by the interviewees}

(2)

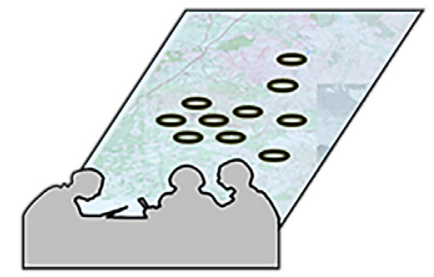

Description of spatial units

(5)

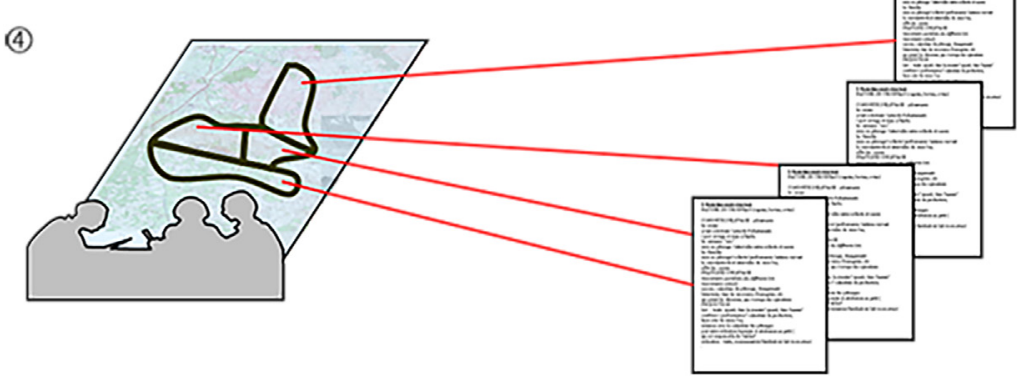

\section{Definition of the territory to be described by the interviewees}

(3)
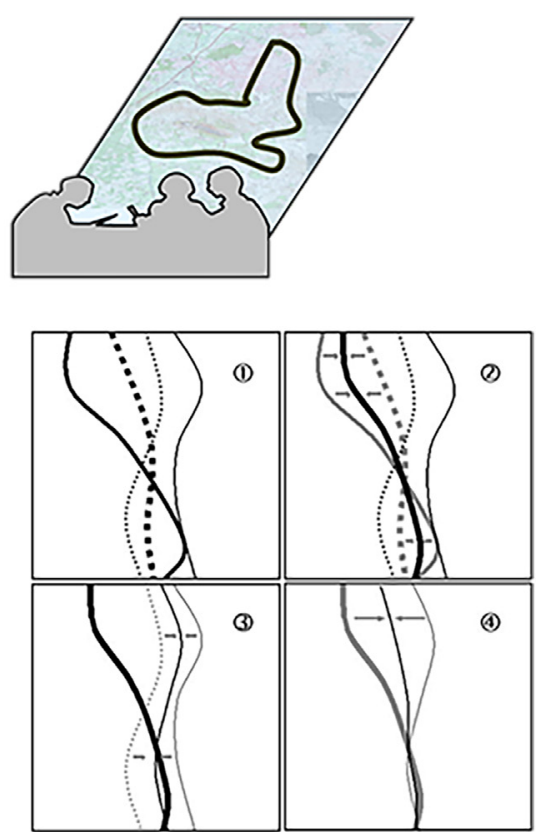

Fig. 2. The different steps of the PBRM-mapping process. 


\section{Results}

\section{Perception-Based Regional Mapping the territory}

The first result of the PBRM territory in the region of Luang Phabang is the power of the territory structure on the habitat but also on the domain of knowledge of the interviewees, constituting thereby strong factors of differentiation within the society. As shown on Figs. 3 and 4, the first point is that very few people have seen their domain of knowledge expanding beyond the borders of the map we have proposed and only along the main road axes, i.e. Vientiane-Luang Phabang-Phongsali or Luang Phabang-Sayabouri. The domain of knowledge of the population, even the ones who belong to non-Lao-Thaï ethnicity, is also strongly restricted, excluding mountains and the areas which were evacuated by the government during the last thirty years.

Beyond these restrictions, the first criterion that can discriminate the domain of knowledge is topography (Fig. 3), splitting the known territory into three portions: lowlands/plains, hills/semimountains and finally mountains. Actually, behind this topographical description lies discrimination in terms of remoteness values. Communication road and river axes play a major role as well:

Geomorphology and topographic: the exclusion and structuring factor

Mountains: combining topography, social "remoteness" and connectivity for territory exclusions. "Mountains" are mainly located over 600-700 $\mathrm{m}$ but are first areas separated from the rest of the territory because of high and steep slopes. They are poorly known by the interviewees (not a single interviewee have visited the Pha Theung mounts eastward of the map; in each village, one or two persons, usually elders, have seen the Pha Xang mounts southward, both areas were mostly evacuated). Mountains are described as remote, with an overall very low accessibility, implying that living there means living on the margins of the society. Rendered equivalent to exclusion, poverty, archaism ("not modern"), mountainous lifestyle is often described pejoratively: stereotypes such as "backward", "lazy" or "bounded" are often used. On the other hand, some interviewees see that, as they live in a hardly accessible place, village communities have de facto considerable autonomy.

Hills and semi-mountains: heterogeneous territory, heterogeneous representations. The mid-mountain areas are described more heterogeneously. Once again, road access and connection ease to cities define the value of a place, alongside the presence of flat valleys, i.e. the potential and/or the existence of irrigated rice ponds. Some areas, though with lower altitude than mountains, are more remote and are therefore described as definitely unattractive. Other semimountain areas have a much more positive connotation thanks to a relatively good road connection and/or they have fertile and productive soils (such as the northern slopes of Pha Xang mounts, close to Luang Phabang). They are then described as "perfect" places of residence, i.e. close to urban centers but affordable without being disconnected from securizing crops. Luang Phabang proximity also provides jobs in secondary and tertiary sectors, from which tourism plays a major and increasing part. Such positions are associated with highly positive values of comfort, development and life quality.

Plains: the regional and national vital thoroughfares. Living in plains means quite systematically a high geographical and social integration. These areas are connected one with an other (for instance, the plain of Luang Phabang and the Mekong is connected with the valley of XiengnGeun through the Nam Khan) and combines all the points that are described by interviewees as absolute advantages: ability to irrigated rice cropping, far more remunerable than upland crops, accessibility to the two market and urban centres (Luang

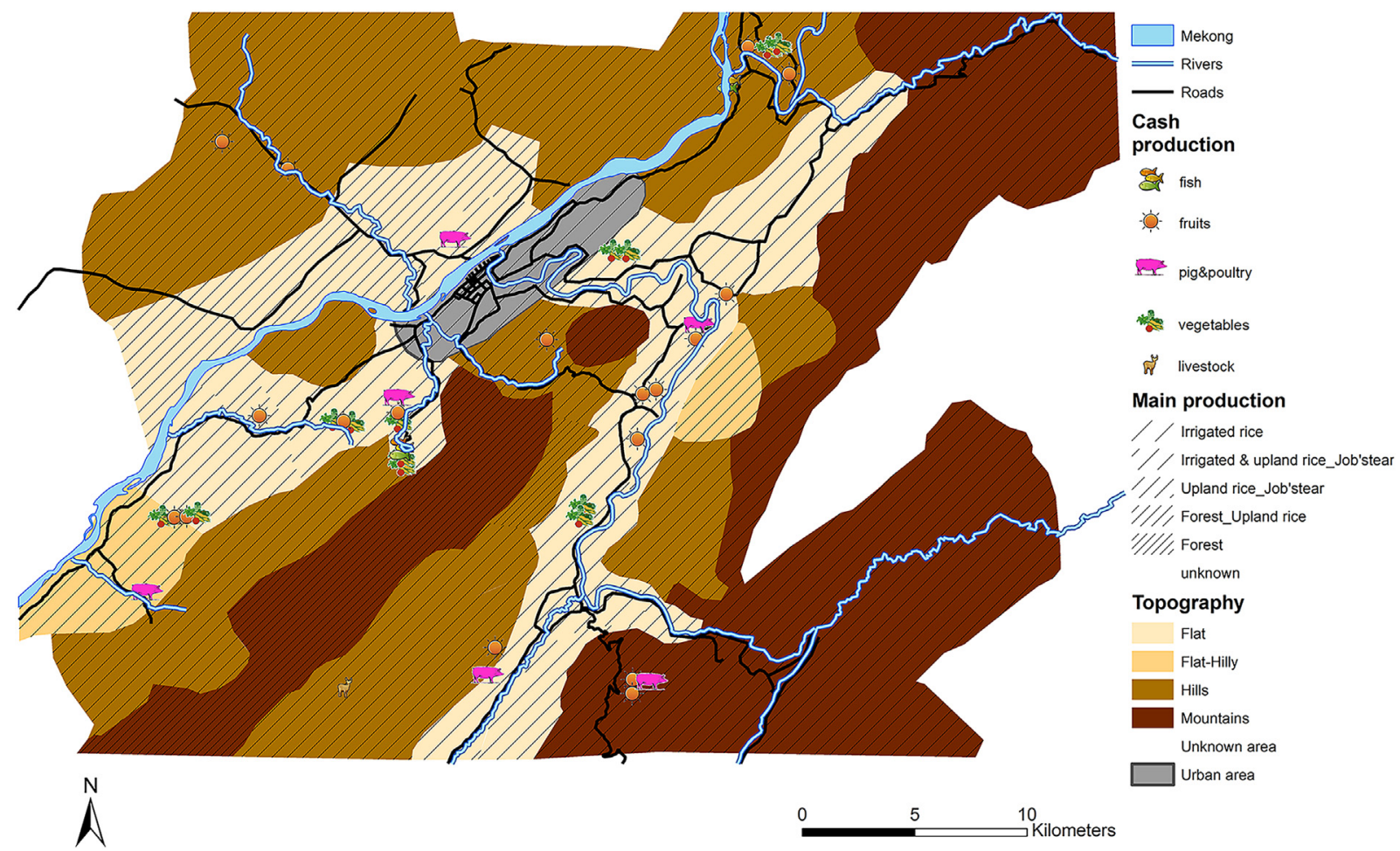

Fig. 3. Topographic organization and Main food and cash productions in the study area. 


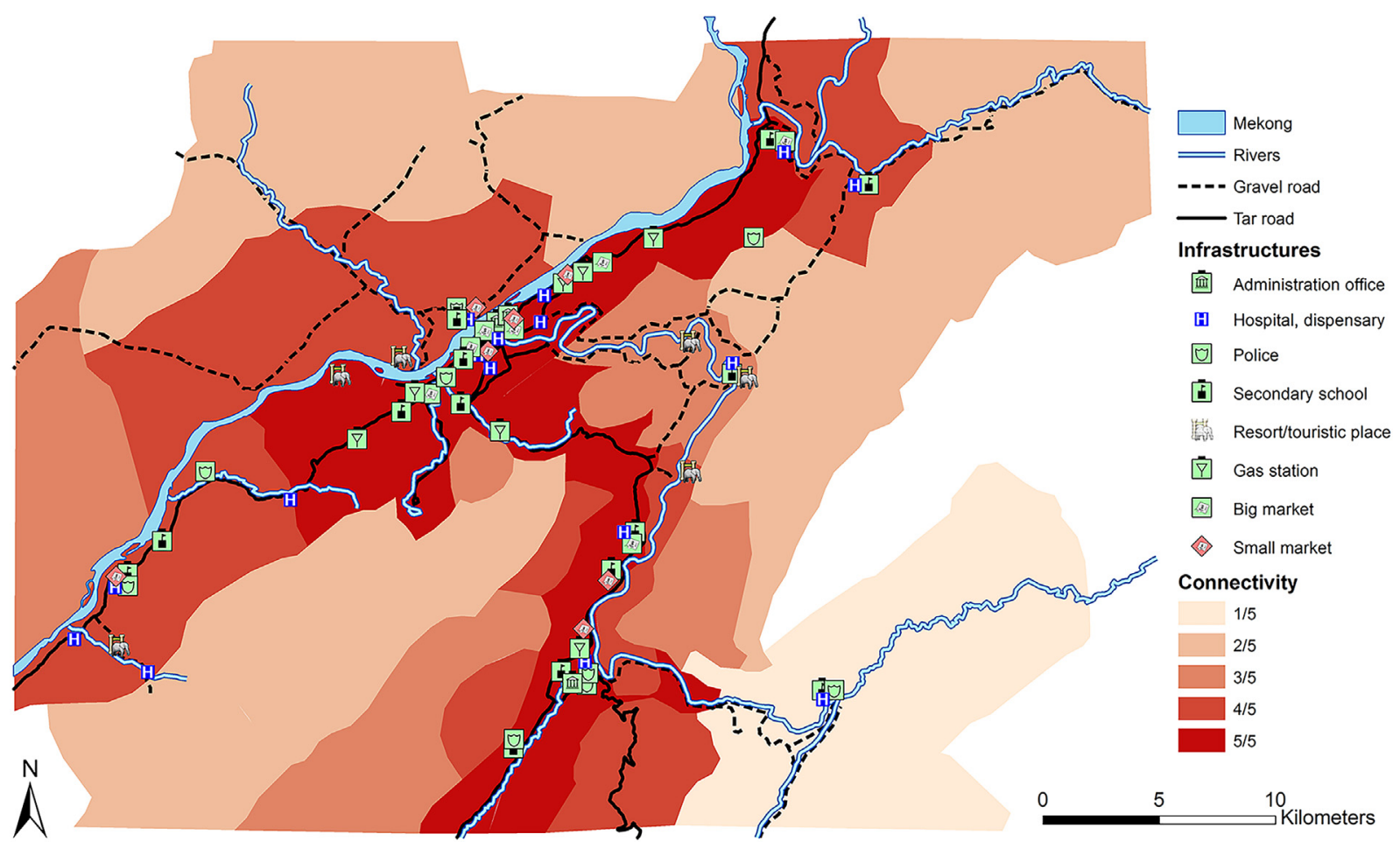

Fig. 4. Differential connectivity and distribution of important infrastructures based on the PBRM health.

Phabang and XiengnGeun) by road. As said previously, this is also the door to city jobs (factories, tourism, trade, etc.).

However, some geographic features such as rivers may constitute natural barriers and isolate flat areas that could have been otherwise attractive. This is the case of villages on the other edge of Mekong in Chômphet District reachable from Luang Phabang only by ferry boat. The same "bad" point applies to plains along but on the other bank of the Nam Khan seen from the tar road: their fertility is renowned but unusable for now, as their products cannot be sent across the Nam Khan. This situation ought to change dramatically in the coming years as one bridge and one dam are already in construction.

\section{Diversification and orientation toward cash crops}

Luang Phabang city had increased dramatically its consumption of food products, especially "high value" ones (irrigated rice, vegetables, fruits, meat), firstly because of the presence of "high consuming" tourists, opening new markets for recently connected areas, such as the hilly area on the northern edge of Pha Xang mounts, connected in 2005. Fruit plantations and pig \& poultry plants have appeared for the last ten years and expand throughout the suitable areas, i.e. well-connected and well-watered quite flat areas.

Rice types of production are of two types: upland areas, i.e. hilly areas and mountains, are dedicated to upland sticky rice crops, mainly for family consumption and self-sufficiency but also for selling surplus to markets, from which Phou Xi market in Luang Phabang plays the most prominent role. Interviewees pointed out two types of rice collecting systems: in areas where road connection is poor, merchants collect rice and other products, with Job's tear as the major one to be sold for the Thailand and china markets. In areas with good roads, groups of villagers come on a regular basis to markets and sell rice and quite the same products near the markets. Flat areas were in contrast previously dedicated to irrigated non-sticky rice, but one should pointed out the shift of irrigated rice fields towards more income-generating vegetable crops all along the tar road connecting Luang Phabang to the southern banks of Mekong river. One may thereby see a general dynamic that discriminates the territory into three zones:

- The urban market supplying area, well-connected, wellwatered, surrounding tar roads and cities, especially Luang Phabang

- New connected often hilly areas where families pursuit selfsufficiency

- Mountainous areas where farms are progressively abandoned due to manpower migration to towns or Luang Phabang suburbs. Families are there moving as a whole or youngsters leave homes for the city. Interviewees pointed out the explosion of teak production on every hill and slope as a consequence, along with the expansion of purchase of land from urban citizen for planting this cash-providing tree.

Connectivity and development: the differential power of inclusion

Topography not only structures the territory but highlights a hub-periphery pattern that concentrates itself without possible and potential retroaction: backward and remote mountains are to be opposed to centres focussing all activities and social interactions.

Roads and regional integration. The uneven development within the region identified during the survey was the first driver to appear during PBRM interviews (Fig. 4). It is closely related with topography as cities and towns, roads, rivers and productive areas are locked together. The road No. 13, which connects Vientiane to Luang Phabang, is often cited as an example: Completed in 1996, a year after the city was listed by UNESCO, this road has allowed the development of the city and tourism. This road is considered as the main "spine" of Laos, as it plays a major National integration role especially through the development of a modern sanitary 
infrastructures system (Mignot, 2003). The same goes for the Road No. 1, built between 2005 and 2006 in the area south-west of Luang Phabang, which has opened the south banks of Mekong to tourism, agricultural trade and ease access to markets of Luang Prabang.

Luang Phabang, the attractive nexus of the area. The city of Luang Prabang is almost always described by the interviewees as the heart of the region, with an indisputable dominance over the territory since many interviewees told us that "everything is in Luang Prabang": Province and District Offices, main economic plants (markets, manufacturing and construction companies, tourist facilities, etc.), hospitals \& clinics. The city is also the major local landmark tourist point, embodied as a UNESCO World Heritage city, and a touristic base for one-day journey trips towards landscape hotspots in the surroundings. Luang Prabang power is also cultural. The capital of the Province of Luang Prabang is the home production of new and/or renewed standards of entertainment and cultural/folk identification, such as the re-invention of boat races.

However, life in the city is sometimes perceived as related to insecurity. New urban people are seen as losing their food selfsufficiency they enjoyed when they lived in the countryside. Such a point, repeated at least three times over interviewees, is revealing the not-so-far fear of hunger coming from the war years. Again, the city is associated with individualization and community solidarity breaking.

A recent dynamic of expansion of the Luang Phabang city. The economic and demographic expansion is not a consequence of the world heritage registration, in 1995, but is more recent and quite sudden, due essentially to tourism and dam construction, opening new credits for government and private investments. This expansion increases spatial disparities, which can be visualized through land prices: land prices between Luang Phabang and PakXuan have shifted in 10 years from amounts per are or ha to amounts per $\mathrm{m}^{2}$, with the same values! Interviewees pointed out that this is due to new migrants but also to Luang Phabang residents moving there as they transform their own houses to tourist guesthouses. Indeed, migration fluxes within the area is described as quasi totally focused on Luang Phabang, with quasi-no settlements in intermediate towns such as XiengnGeun, B. MuangKhai or Chômphet. On the other hand, they clear remote areas, without the "need" of governmental "evacuations": families abandon their land plot to migrate to more "connected" places, but the price differential imposes to ask for the support of relatives.

\section{Perception-Based Regional Mapping health issues}

\section{Health issues and problems: mountain, rivers and city waters}

The overall open question asked to interviewees is: "Concerning/about health issues, is it everywhere the same?" as the research team was expecting a first differentiation according to diseases and problems. Vector-borne and parasitic diseases were characterized by respondents as related to cleanliness. As seen above, cities like Luang Phabang are perceived as not totally positive, along contrasted points of view: they appear as "clean", thanks to a garbage collection system but also as "dirty", because of dirt, overcrowd and stagnant waters (streams, ditches, systematically flooded areas) where mosquitoes proliferate and where episodes of diarrhoea, "malaria" and dengue may and has already occurred. Moreover, hospitals are described as a cause for the presence of sick people. The city, and mostly the area in Luang Phabang surrounding the southern Pho Si market but also its northern part beyond the Nam Khan, is then seen as a sickness haven. This city-sickness connection is also noticed for smaller towns, XiengnGeun and PakXuan. Living in high population density environments is then a criterion that highlights the opposition between urban and rural areas. As pointed out by Ribolzi et al. (2011), the diseases (dengue and "malaria", diarrhoeic episodes) were described as progressively restricted to flood episodes during the monsoon (Fig. 5). Interviewees did not manage to discriminate these two diseases and the four physicians (one medical doctor, three nurses) were talking of both diseases. Diarrhoeic cases occur during flood episodes at the beginning of the monsoon and from April to June because people, while working in fields, take less care about water quality they drink. Vector-borne diseases are observed all along the monsoon, from July to September.

The fact that towns are now easily connected by roads has increased the number of sick people coming to town hospitals. Indeed, following the elderly respondents during the survey, the situation has dramatically changed: sanitary conditions are described to have been "very good" in the 80's in cities such as Luang Phabang because there was "less people so less dirt". Beyond the common "good old time" argument, this illustrates the rapid change that has occurred for the last decades.

Apart from "dirty" places in towns, "unhealthy" places are remote places, where people drink and/or are in contact with contaminated water during the warm season (April to June): it corresponds to a period of land cropping, where farmers work in fields, with no time for coming back to villages for drinking boiled water, when boiling water is not even easy. Moreover, roads to such areas are often impracticable, especially during this period, implying that bottled water is not available at this season and even never in some places. This applies in almost all mountains all along the year but also along the Mekong and the Nam Khan rivers and main tributaries during this season (Fig. 6).

\section{Health remediation: an aureole pattern of accessibility}

Access to health remediation facilities. Regarding health remediation, the medical infrastructure density raises as the most noticed criterion for spatial differentiation, to be linked with the accessibility to these medical facilities (Fig. 7). The city of Luang Phabang is well equipped in hospitals, at least in numbers of hospitals (at least four public and military ones and several private clinics), followed by the town of XiengnGeun. Cities are also the centres of several medical and hygiene extension programs (vaccination, latrine program, animal disease prevention, mosquito net campaigns, $3 \mathrm{C}$ program: "Stay Clean, Drink Clean, Eat Clean").

Therefore, the territory can be then divided in two portions: a large centered aureole is well-connected thanks to good and allseason roads, allowing the travel to reach medical facilities roughly similar in time (the measurement is in minutes or hours, according to interviewees), although it need at least 30 min more crossing the Mekong. Mountains and areas separated by a still impassable river, on the other side of the ranking, are the places with the highest difficulty for medical care. For instance, the inhabitants of still occupied villages of the upper watershed of the Nam Bak river, a tributary of the Nam Khan, (B. Thaphong and B. Phonia) may have to walk one or two days, according to the settlement and the season, to reach PakBak! The right edge of the Mekong is also an area of less accessibility to medical facilities: dispensary density is lower; roads are all gravels, often submerged and impracticable during the monsoon, especially in its beginning.

As a matter of fact, several interviewees did hierarchies the medical network: apart from places directly connected to important medical centers, local dispensaries are dedicated to "small" diseases and the first diagnosis while going to the main city (Luang Phabang and XiengnGeun) is restricted to serious sicknesses, organizing thereby the territory into concentric aureoles around dispensaries and bigger aureoles for city hospitals (Fig. 7). 


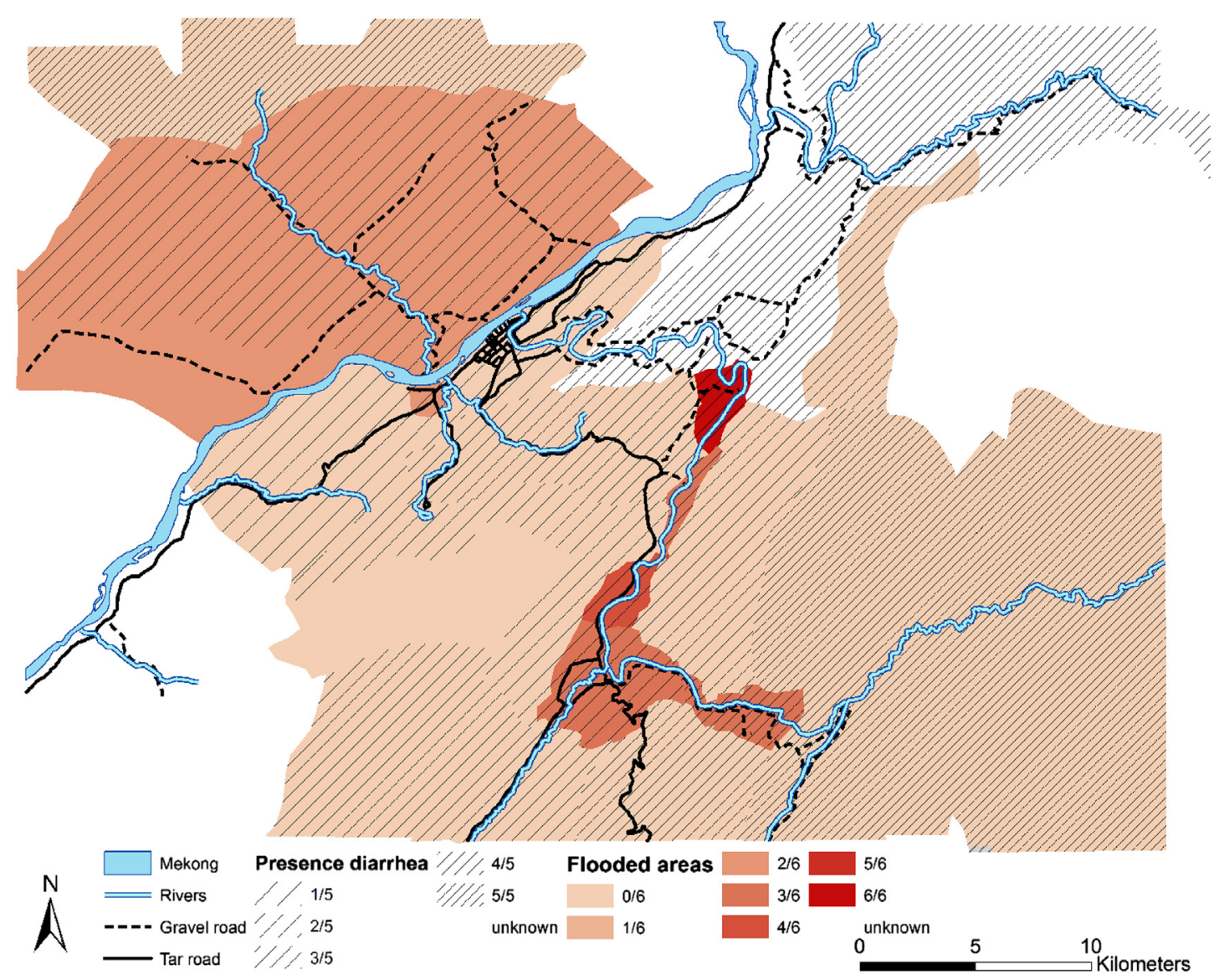

Fig. 5. Presence of Diarrhoeic episodes and position of the last floods.

Access to potable water. The second criterion for discriminating the territory is also linked to accessibility and the quality of road and transportation infrastructure: it concerns the access to potable water.

It is indeed very difficult for a developing country like Laos to build a tap water infrastructure. The de facto solution may be seen as the translation to potable water of the phone shift from wired to wireless mobile networks. Villages are supplied with potable water 20-45-1 plastic bottles, from several water factories in the area (Fig. 7). This supply network is very recent, since 2000 for the firstserved places until 2008 and still continuing. Bottle costs vary according to distance and road quality but not that much (4000-5000 LAK, i.e. 0.4 to $0.5 €$ per 20l-bottle), thanks to what have been described as a governmental subvention. Indeed, cities are connected with quite potable tap water (Daviau, 2011; French Red Cross, pers. com.) along with bottled water extensively. We point out the extremely rapid adoption of such a decentralised water distribution. Spatial differentiation remains between houses with a direct connection to public tap water (such as in Banh Lak Sip) and those without, where people fetch water to public taps, saving de facto water because of the difficulty to bring it back home. In the first case, families spend water that stagnates near houses, enhancing the proliferation of mosquitoes.

Thereby again, the territory is divided between the wellconnected aureoles where bottled water is available all along the year and is quasi-systematically used, and the rest, mainly mountainous. Within these remote areas, extension power has created an other differentiation: most of the villages are used to boil water while very remote ones still drink non-boiled water as it was practiced "twenty years ago", a not-so-far period, illustrating the rapid change that had occurred here. Therefore, we assume that this water organization depends upon the connectivity: water access is the crystallization of the growing spatial discrimination regarding connectivity.

\section{Discussion \& conclusion}

The limitations of the Perception-Based Regional Mapping regarding health issues

The studied territory is not representative of northern Laos, because of its proximity to the city of Luang Prabang. One may suggest testing the tool on a more remote territory with less contrasted situations. As said in Saqalli et al. (2009), the last mapcombining step of the method is very time-consuming, which decreases the time efficiency of the field steps. SHU limits are geographically precise regarding topology but not spatiality. For instance, disease zones define villages where diseases were observed but not the specific spatial expand of epidemics.

Social and political structure unique to Laos is also an important factor: if villages were selected by the team, villagers were proposed by village representatives to the DAFO. Although the representativeness is not so bad $(23 \%$ and $30 \%$ of no-members of organizations for the territory and the health PBRMs respectively against around half of the population in each village), the fact that the choice of interviewees is not totally free and that interviews were assessed in the presence of officials (DAFOs, village officials sometimes) open the questioning on the representativeness of respondents and the objectivity of responses.

If the PBRM method is indeed relevant for spatializing territory organizations and uses, the process appeared to be more difficult once we implemented it for a specific issue such as health: As it is a 


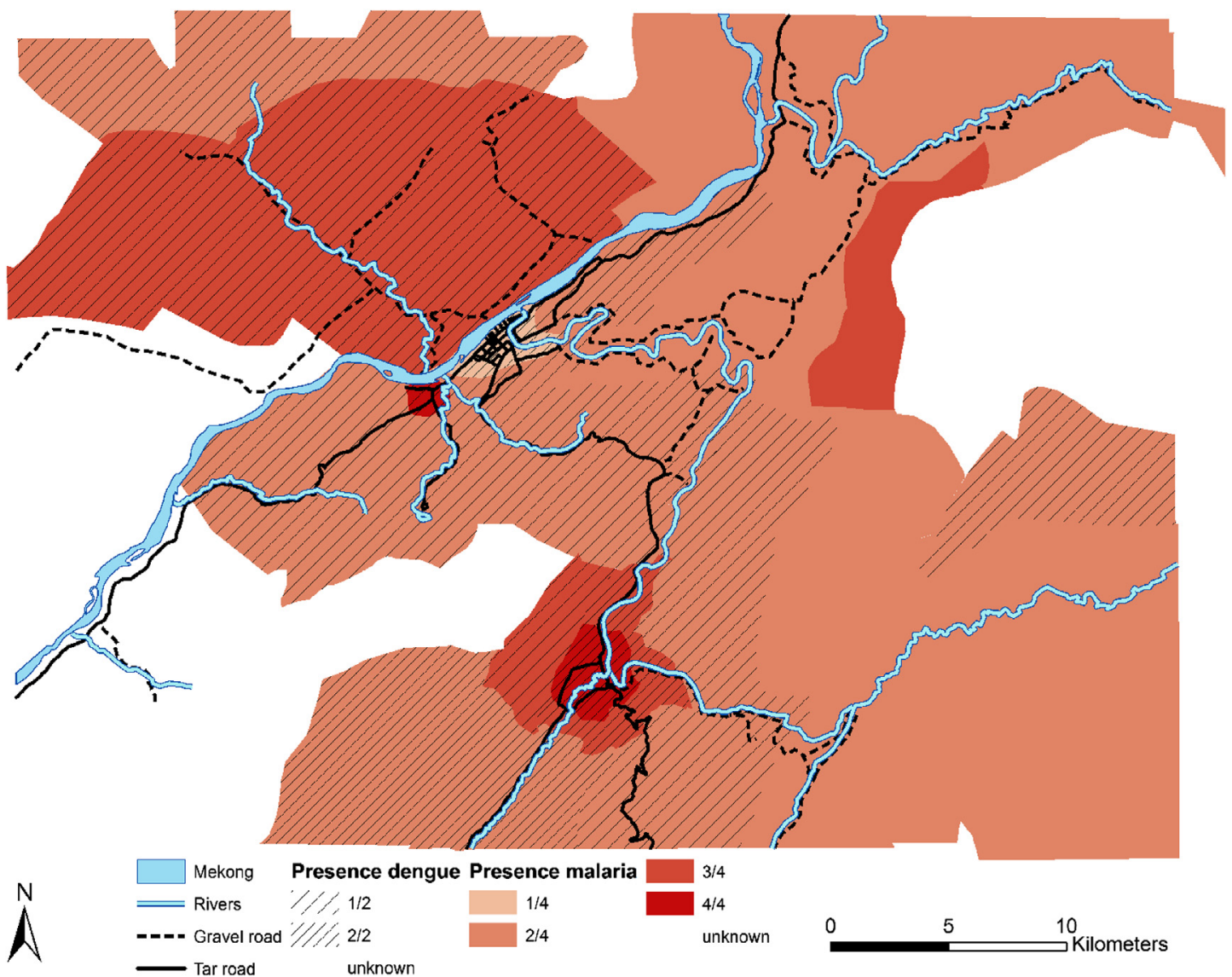

Fig. 6. Presence of "Malaria" and Dengue.

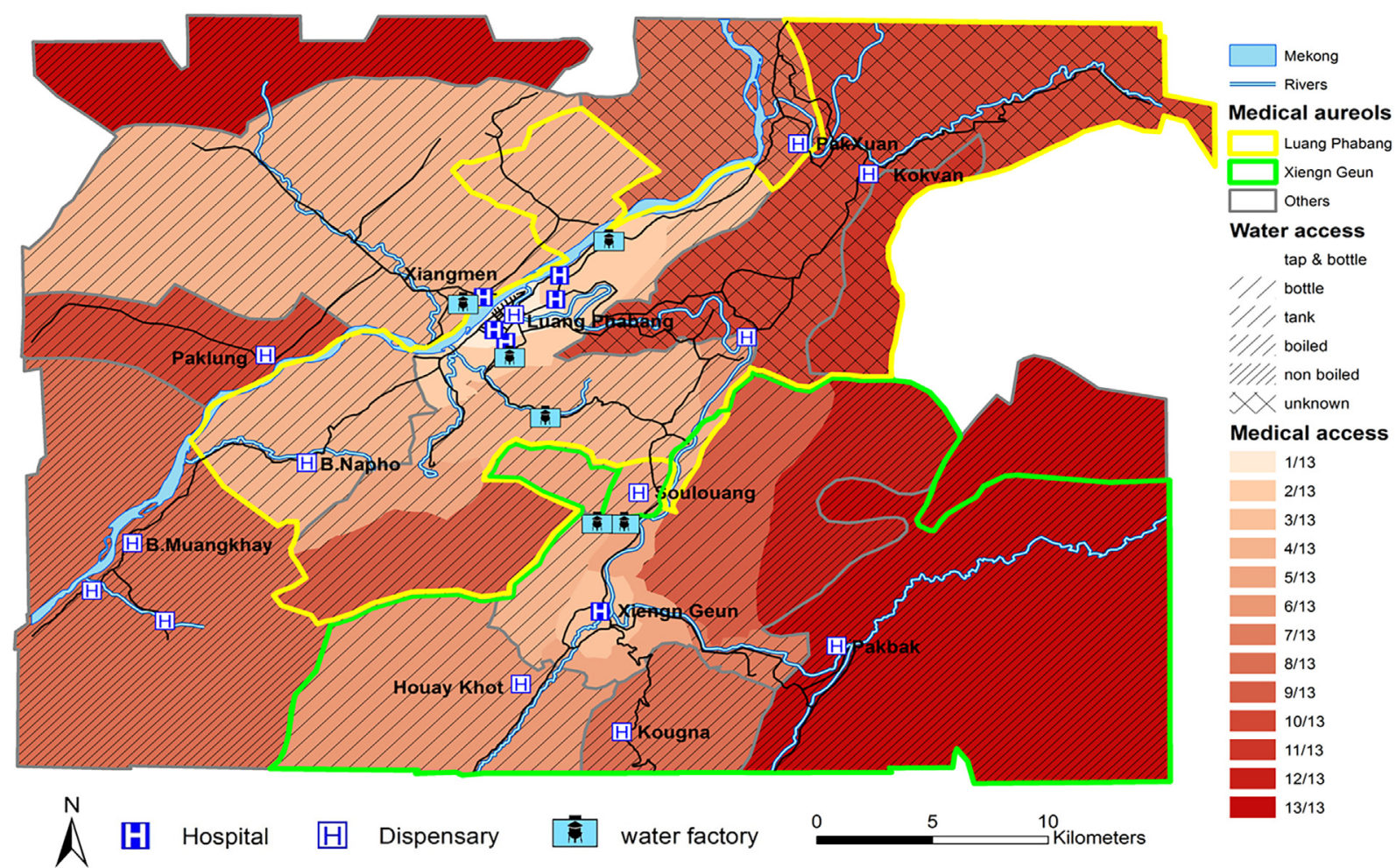

Fig. 7. Medical aureoles surrounding dispensaries and hospital centres and medical and water access in the study area, according to PBRM health interviewees. 
less open issue than territory, interviewees found difficult to elaborate informations on it and even more to discriminate the territory regarding health criteria. Moreover, as it is a technical issue, non-specialists may built confusion, especially when identifying diseases people were suffering. As said previously in Saqalli et al. (2009), it is not totally linked to disease issues but to a broader misunderstanding of local meanings. The most prominent example was the probable use of the word "malaria" for designating dengue. No clear distinction could have been made between these two diseases.

Interview results have shown that, despite (and maybe thanks to) the strong involvement of the government, health seems to not be a major issue (anymore?). The standard of living is rather emerging as a more important local issue. The method also does not give an easy access to non-spatial criteria but it can quickly highlight various issues, spatial and non-spatial, opening thereby new fields to scientists from various specific disciplines may investigate but also public services may question for adapting local healthrelated policies. For instance, the PBRM results could for example allow the production of dangerousness/vulnerability maps, linking environmental factors, sickness ecology and prospective projections for future human developments, to validate with epidemiological data.

\section{A fast and low-cost assessment of a broad area regarding health issues}

The PBRM explores broader issues at a broader scale for exploring what issues are prominent. It explores human dynamics at a broader level than other Rapid Diagnosis tools (Chambers, 1994; Saqalli et al., 2009).

Some of the results are counter-intuitive: For instance, the water bottle system dramatically increases the area where potable water is accessible. The health issue is then limited to punctual uprisings. Diarrhoeic episodes seem to be gradually restricted to children accidents. Thanks to a fast-growing road network, the area will even expand until the limit of the evacuated zones and the mountains. The economic impact of Luang Phabang is higher than expected, cannibalizing the economic power of surrounding towns such as XiengnGeun. The link between erosion and diseases has not been pointed out by interviewees, even physicians and nurses.

As a regional level tool, it underlines new points, such as growing one-side fluxes, for nourishing the growing city of Luang Phabang (fruits, vegetables and livestock) or for the foreign markets (fruits, job's tear, teak), but also the temporal human dynamics, characterized by a growing circular hierarchization of the whole territory along aureoles around Luang Phabang. Finally, the tool helped to actualize the network of infrastructure facilities: In our case, public buildings such as markets, roads but also canals, dams, water castles, secondary schools, etc. (not shown on maps) were revealed and the medical network has been actualized.

These results are action-oriented. Beyond any populous postulate (Olivier de Sardan, 2010), considering development actions upon this approach is more focused on local and developmentoriented issues. For instance, the necessity of a drinking water cleaning network has been wiped out thanks to the water bottle system. Although private and thereby potentially submitted to price variations, this system has oriented the priority towards medical accessibility and thereby on roads and transportation services throughout the region.

Again, the PBRM should avoid the panacea role PRAs (Participative Rural Appraisals) had played for decades; however, this tool provides a local perception-based guideline for developing new approaches on such issues. It thus supports the objectives of development agencies and researchers. Meanwhile, because the legitimacy of this tool is based on stakeholders, and because it may elaborate contradictions with assumptions from other sciences, one should acknowledge the subsequent necessity of opening the debate among scientists and between scientists and policy stakeholders. As pointed out by Olivier de Sardan (2010), "Without a joint production of research issues and domains, a combined quantitative and qualitative approach may remain a partnership show-off".

\section{Acknowledgements}

This research has been supported by the PEPS project $n^{\circ} 107$ MIASMES- Flood-Related Diseases: A Socio-spatial Approach of Mekong and its tributaries and PASTEK: impacts of global change on water resources in terms of volume and quality in the Nam Khan basin.

\section{References}

Campbell, I. C. (2007). Perceptions, data, and river management: lessons from the Mekong River. Water Resources, 43(2), W02407.

Caron, P. (2001). Zonage À Dires D'acteurs: Des Représentations Spatiales Pour Comprendre, Formaliser et Décider. Le Cas de Juazeiro, Au Brésil. In S. Lardon, P. Maurel, \& V. Piveteau (Eds.), Représentations Spatiales et Développement Territorial (pp. 343-357). Paris, France: Hermes Sciences Publications.

Chambers, R. (1994). Participatory rural appraisal (PRA): analysis of experience. World Development, 22(9), 1253-1268.

Daviau, S. (2011). Final evaluation of the French red cross community based health program Sayabouly and Vientiane province, Lao PDR (2008-2011). French Red Cross, Lao Red Cross, and Lao Ministry of Health.

Evrard, O. (2006). Chroniques des cendres: Anthropologie des sociétés khmou et des dynamiques interethniques du Nord-Laos. France: IRD Montpellier.

Komany, S. (2008). Water quality monitoring and management in Lao P.D.R.: the case study of Nam Ngum River Basin. In The 3rd WEPA international forum on water environmental governance in Asia. Putrajaya, Malaysia.

Lestrelin, G., \& Giordano, M. (2006). Upland development policy, livelihood change and land degradation: interactions from a Laotian village. Land Degradation and Development, 17, 1-22.

Loader, R., \& Amartiya, L. (1999). Participatory rural appraisal: extending the research methods base. Agricultural Systems, 62, 73-85.

Maestripieri, N., Saqalli, M., Veyrac-ben Ahmed, B., Becerra, S., Munoz, M., Yanez, E., et al. (2014). Assessing health risk using regional mappings based on local perceptions: A comparative study of three different hazards in three sites: Laos, Tunisia and Ecuador. Porto, Portugal: International Congress on Environmental Health.

Mekong River Commission Secretariat. (2010). Social impact monitoring and vulnerability assessment: report on a regional pilot study for the Mekong corridor. MRC Technical Paper, 30, 1683-1489.

Mignot, F. (2003). Santé et intégration Nationale au Laos, Rencontres entre montagnards et gens des plaines, L'Harmattan, coll. Rencontres Asiatiques.

Nackoney, J., Rybock, D., Dupain, J., \& Facheux, C. (2013). Coupling participatory mapping and GIS to inform village-level agricultural zoning in the Democratic Republic of the Congo. Landscape and Urban Planning, 110, 164-174.

Norris, T. B. (2014). Bridging the great divide: state, civil society, and 'participatory' conservation mapping in a resource extraction zone. Applied Geography, 54, $262-274$.

Olivier de Sardan, J.-P. (2003). L'enquête socio-anthropologique de terrain: synthèse méthodologique et recommandations a' usage des étudiants. Etudes \& travaux du LASDEL, 13.

Olivier de Sardan, J.-P. (2010). Anthropologie médicale et socio-anthropologie des actions publiques. Anthropologie et santé, 1(86).

Ribolzi, O., Patin, J., Bresson, L.-M., Latsachak, K. O., Mouche, E., Sengtaheuanghoung, O., et al. (2011). Impact of slope gradient on soil surface features and infiltration on steep slopes in northern Laos. Geomorphology, 127(1-2), 53-63.

Saqalli, M., Caron, P., Defourny, P., \& Issaka, A. (2009). The PBRM (perception-based regional mapping): a spatial method to support regional development initiatives. Applied Geography, 29(3), 358-370.

Saqalli, M., \& Dosso, M. (2011). Draped heterogeneity, forced uniformity: When agroenvironmental policies drive family evolutions : The U Minh Thương forest reserve, Mekong delta, Vietnam. Field Actions Science Reports, 5.

Saqalli, M., Mouri, H., Becerra, S., Muñoz, M., Abdessamad, I., \& Touati, M. (2013). Perception et qualification de la contamination métallique autour de l'ancien site minier du Jebel Ressas, Tunisie: Étendue et poids par une approche spatialisée à dires d'acteurs. Sousse, Tunisia: Colloque "Contaminations Métalliques".

UN-Habitat. (2008). Impact assessment study for the community-based water and sanitation Project: Xieng Ngeun town, Xieng Ngeun district, Luang Prabang province, Laos. UN-Habitat.

World Health Organization (WHO), United Nations Children's Fund (UNICEF) (2006). Meeting the MDG (Millennium development goals) drinking water and sanitation target: The urban and rural challenge of the decade. WHO library cataloguing-in-publication data, WA 675. Geneva, Switzerland: WHO Press. 